\title{
Assessment of the Results of Blood Cultures Taken in the Pediatric Clinic of a Training and Research Hospital in Mogadishu, Somalia
}

\section{Somali Mogadişu'da Bir Eğitim ve Araştırma Hastanesinin Çocuk Kliniğinde Alınan Kan Kültürlerinin Sonuçlarının Değerlendirilmesi}

\author{
D Cüneyt Uğur' \\ 'Department of Pediatrics, University of Health Sciences Turkey, Konya Health Application and Research Center, Konya, Turkey
}

\begin{abstract}
Aim: The aim of this study is to determine the distribution of microorganisms isolated in blood culture and their antibiotic susceptibility retrospectively.

Materials and Methods: This study was conducted at the Mogadishu Somalia Türkiye Recep Tayyip Erdogan Training and Research Hospital. A total of 76 patients who were hospitalized to the pediatric clinic between the years of 2016 and 2018, who had significant reproduction in their culture tests and whose samples was performed antibiogram test were included. Demographic datas, microorganism strains and antibiogram results of these patients were recorded.

Results: The subjects of this study were 37 females (48.7\%) and 39 males (51.3\%). The mean age of the subjects was $4.68 \pm 4.74$ ( 1 month-18 years) years. 57 (75\%) of the reproduced microorganisms were Gram-positive bacteria, and 19 (25\%) were Gram-negative bacteria. The most commonly isolated bacteria was coagulasenegative staphylococci (CoNS) by $36.8 \%$. It was followed by Staphylococcus aureus by $19.7 \%$. The most commonly isolated Gram-negative bacteria was Escherichia coli by $6.6 \%$. The antibiotic resistance of CoNS was highest against penicillin G by $85.7 \%$, ampicillin-sulbactam by $78.6 \%$ and trimethoprim sulfamethoxazole by $75 \%$. The antibiotic resistance of Staphylococcus aureus was also highest against penicillin G (86.7\%), ampicillin-sulbactam (80\%) and trimethoprim sulfamethoxazole (73.3\%).

Conclusion: It was thought that necessary that determining the microorganisms reproduced in blood culture and their antibiotic susceptibility as periodic and that taking the results of such studies into account while designing appropriate empirical therapy.
\end{abstract}

Keywords: Somalia; child; bloodstream infection; blood culture; antibiotic susceptibility.
Öz

Amaç: Bu çalışmada, kan kültüründe üreyen mikroorganizmaların dağılımının ve antibiyotik duyarlılığının geriye dönük olarak belirlenmesi amaçlandı.

Gereç ve Yöntem: Bu çalışma Mogadishu Somali Türkiye Recep Tayyip Erdoğan Eğitim ve Araştırma Hastanesinde yapıldı. 2016-2018 yılları arasında çocuk servisine yatırılan, kan kültüründe anlamlı üreme olan ve antibiyogram testi yapılan 76 hasta dahil edildi. Bu hastaların demografik verileri, mikroorganizma türleri ve antibiyogram sonuçları kaydedildi.

Bulgular: Hastaların 37'i kız (\%48,7), 39'ü erkek (\%51,3) idi. Hastaların yaş ortalaması 4,68 \pm 4,74 yıl olup, yaş aralığı 1 ay - 18 yıl idi. Üreyen mikroorganizmaların 57'si (\%75) gram pozitif bakteri, 19'u (\%25) gram negatif bakteri idi. En sık izole edilen etken \%36,8 ile koagülaz negatif stafilokok (KNS) idi. Bunu \%19,7 ile Staphylococcus aureus takip etmekte idi. Gram negatif bakteriler içinde en sık izole edilen ise \%6,6 ile Escherchia coli idi. KNS'da antibiyotik direnci en fazla \%85,7 ile penisilin G, \%78,6 ile ampisilin-sulbactam ve \%75 ile trimetoprimsulfametoksazol'a karşı idi, Staphylococcus aureus"ta ise antibiyotik direnci en fazla \%86,7 ile penisilin G, \%80 ile ampisilin-sulbactam ve \%73,3 ile trimetoprim-sulfametoksazol'a karşı idi.

Sonuç: Belli aralıklarla kan kültüründe üreyen mikroorganizmaları ve bunların antibiyotik duyarlılığını belirlemenin ve uygun ampirik antibiyotik şeçiminde bu çalışmaların sonuçlarını dikkate almanın gerekli olduğu düşünüldü.

Anahtar Kelimeler: Somali; çocuk; kan doiaşımı enfeksiyonu; kan kültürü; antibiyotik duyarlılığı.

Corresponding (IIletişim): Cüneyt Uğur, Department of Pediatrics, University of Health Sciences Turkey, Konya Health Application and Research Center, Konya, Turkey

E-mail (E-posta): cugur70@gmail.com

Received (Geliş Tarihi): 07.11.2019 Accepted (Kabul Tarihi): 08.04.2020 


\section{INTRODUCTION}

Bloodstream infections (BSIs) are medical condition with high morbidity and mortality despite antimicrobial treatments. They extend hospitalization periods, increase resistance to antibiotics and cause increase in healty spendings. ${ }^{[1-2]}$ The epidemiology of pediatric BSI is affected by various factors such as age, nutritional condition, vaccination coverage and geographical location. ${ }^{[3]}$ Infections related to medical care in developing countries have a very limited coverage in the scientific literature. ${ }^{[4]}$ Pediatric BSI in Sub-Saharan Africa constitutes as a major medical burden. ${ }^{[5-9]}$

Microorganisms causing BSIs have a wide range. Gram-positive cocci (staphylococci, streptococci and enterococci) and Gramnegative bacilli (Pseudomonas Aeruginosa, Escherichia Coli, Acinetobacter, Klebsiella strains) are the most frequently encountered causes. Besides bacteria, fungi such as Candida strains are also responsible for causing BSIs. ${ }^{[1,10]}$

Blood culture tests are widely used for isolation of BSI-causing microorganisms. Correct identification of infection factors and their antibiotic susceptibilty holds the utmost importance in designing a successful treatment plan and decreasing mortality. Distribution and antibiotic susceptibilty of BSIcausing microorganisms vary based on years and regions. For these reasons, every hospital needs to monitor the distribution of these microorganisms and the their antibiotic susceptibilty in terms of guiding an empirical treatment. ${ }^{[11,12]}$

The purpose of this study is to identify distribution of the microorganisms isolated in blood culture and their antibiotic susceptibilty together with the demographic characteristics of the subjects. Because there are no prior studies on this subject that were conducted in this region in the scientific literature. With this study, it is hoped to offer appropriate empirical treatment options and prevent antibiotics resistance, from forming by identifying the most common microorganisms in this region and their antibiotic susceptibility.

\section{MATERIAL AND METHOD}

This study was conducted at the Mogadishu Somalia Türkiye Recep Tayyip Erdogan Training and Research Hospital. The study was carried out by retrospective analysis of the blood culture test records kept in the automation system of the pediatric clinic between the years of 2016 and 2018 . Patients who were between 1 month old and 18 years old that significant reproduction in their culture tests and whose samples received antibiogram were included in this study. Duplicate samples of the same subjects and samples thought to be contaminated with skin flora were excluded from this study. 93 patients were included in the study. 11 of them because of contamination and 6 of them because of double samples were excluded from this study. The demographic datas, the strains of reproducing microorganism and the results for antibiogram tests of 76 patients whose samples met the criteria of this study were registered.
Culture samples were incubated using the BACTEC 9050 (Becton Dickinson, ABD) blood incubation system. Vials with positive signals were passaged into blood agar, chocolate agar and ethylene blue media. Identifications performed by conventional practices were verified with the Analytical Profile Index (BioMerieux, France) when needed. Antibiograms of the reproduced microorganisms were conducted in accordance with the Kirby-Bauer Disk Diffusion method and the criteria of the Clinical and Laboratory Standards Institute. ${ }^{[13]}$

Approval was obtained from the ethics committee in the hospital where the study was conducted. The study was also conducted in accordance with the Declaration of Helsinki.

Supplementary statistical analyses were used. The categorical variables were signified with frequency (n) and percentage (\%) values. For the comparison of the categorical variables, chi-squared test was utilized. For every statistical analysis, the Statistical Package for the Social Sciences Windows Software (ver. 22; IBM SPSS, Chicago, USA) was used.

\section{RESULTS}

The subjects of this study were 37 females (48.7\%) and 39 males (51.3\%). The mean age of the subjects was $4.68 \pm 4.74$ years, and the subjects were between 1 month and 18 years of age. 57 (75\%) of the reproduced microorganisms were Grampositive bacteria and 19 (25\%) were Gram-negative bacteria. The most commonly isolated bacteria was coagulasenegative staphylococci (CoNS) by $36.8 \%$. It was followed by Staphylococcus aureus (S. aureus) by $19.7 \%$. The most commonly isolated Gram-negative bacteria was Escherichia coli (E. coli) by $6.6 \%$. Strains of the reproduced microorganisms and their frequency are shown in Table 1.

\begin{tabular}{lcc}
\multicolumn{3}{l}{ Table 1. Strains and frequency of the reproduced microorganisms } \\
Microorganisms & $\mathrm{n}$ & $\%$ \\
\hline Gram-positive bacteria & 28 & 36.8 \\
CoNS & 15 & 19.7 \\
Staphylococcus aureus & 4 & 5.3 \\
Staphylococcus intermedius & 3 & 3.9 \\
Enterococcus faecium & 1 & 1.3 \\
Streptococcus pyogenes & 1 & 1.3 \\
Streptococcus pneumoniae & 5 & 6.6 \\
Kocuria kristinae & & \\
Gram-negative bacteria & 5 & 6.6 \\
Escherchia coli & 4 & 5.3 \\
Pseudomonas aeruginosa & 3 & 3.9 \\
Klebsiella pneumoniae & 2 & 2.6 \\
Acinetobacter baumannii & 1 & 1.3 \\
Acinetobacter twoffii & 1 & 1.3 \\
Burkholderia cepacia & 1 & 1.3 \\
Moraxella lacunata & 1 & 1.3 \\
Stenotrophomonas maltophilia & 1 & 1.3 \\
Yersinia pseudotuberculosis & 76 & 100 \\
Total & & \\
\hline CoNs: Coagulase negative staphylococci &
\end{tabular}


The antibiotic resistance of CoNS was highest against penicillin $\mathrm{G}$ by $85.7 \%$, ampicillin-sulbactam (SAM) by $78.6 \%$ and trimethoprim sulfamethoxazole (TMP-SMX) by $75 \%$. The antibiotic resistance of $\mathrm{S}$. aureus was also highest against penicillin G (86.7\%), SAM (80\%) and TMP-SMX (73.3\%). The antibiotic resistance of Gram-positive bacteria is shown in Table 2.

The antibiotic resistance of E. coli was the highest against TMPSMX by $80 \%$ and against ampicillin, amoxicillin clavulanate (ACA), ceftriaxone and cefoxitin by $60 \%$. The antibiotic resistance of Gram-negative bacteria is shown in Table 3.

\section{DISCUSSION}

Bloodstream infections in children, if not treated with appropriate antibiotics, may result in complications and mortality and cause antibiotic resistance to develop. ${ }^{[1,11,14]}$ Thus, assessment of the distribution of isolated microorganisms and their antibiotic susceptibility as periodic for every region and hospital is important in selecting appropriate treatment. This study show that the appropriate antibiotics for treatment of BSIs in this region to be, linezolid, vancomycin and clindamycin for Gram-positive bacteria, and imipenem, amikacin and gentamicin for Gram-negative bacteria. In

Table 2. Antibiotic resistance rates of gram-positive bacteria

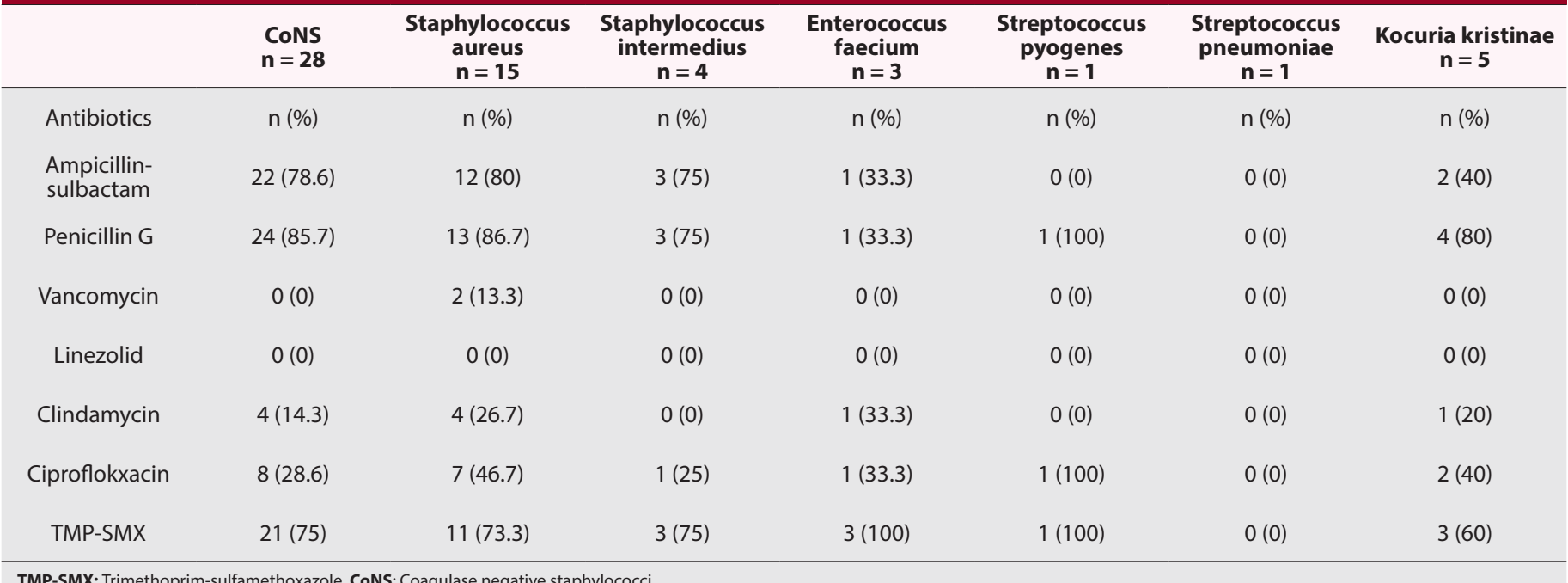

TMP-SMX: Trimethoprim-sulfamethoxazole, CoNS: Coagulase negative staphylococci

Table 3. Antibiotic resistance rates of gram-negative bacteria

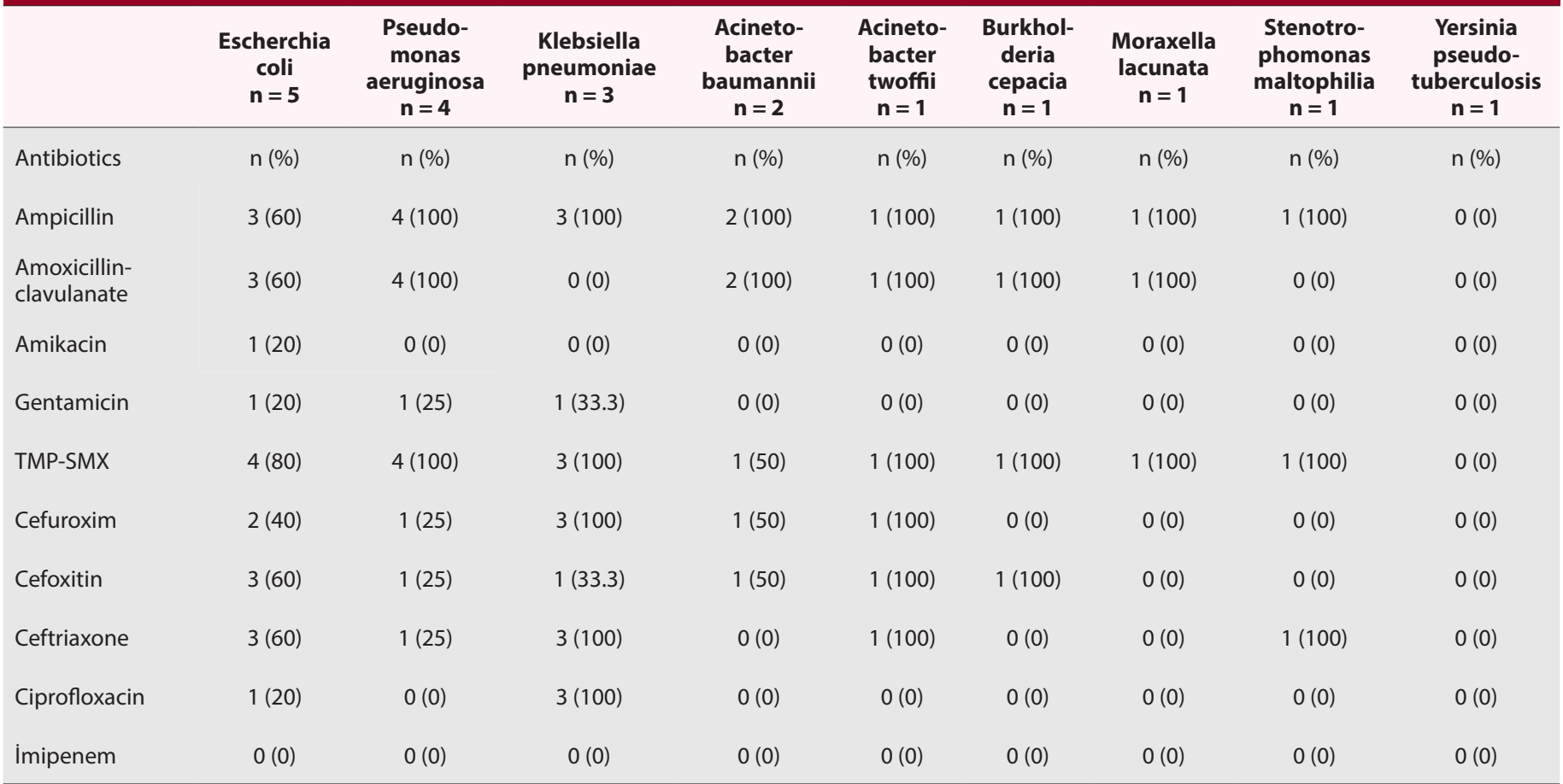


empirical treatment, combination of effective an antibiotic to Gram-positive bacteria with, and effective an antibiotic to Gram-negative bacteria will be more suitable.

When prior studies on BSI were examined, it was established that while Gram-negative bacteria were prevalent in the 1960s and 1970s, in 1980s, an increase in the frequency of Gram-positive bacteria was observed. ${ }^{[15,16]}$ In current studies, the most commonly isolated bacteria were reported to be Gram-positive bacteria at a detection rate between 59.8\% and $80 \% \cdot{ }^{[11,17-19]}$ Furthermore, the most commonly isolated microorganism was reported to be CoNS..$^{[1,17-20]}$ Moreover, in this study, the most commonly isolated bacteria were Grampositive bacteria (75\%), and the most commonly isolated microorganism was CoNS.

In the study conducted by Karlowsky et al. ${ }^{[20]}$ in United States, they reported that CoNS had the highest antibiotic resistance against penicillin (68.3\%) and erythromycin (40.8\%).In the study conducted by Reynolds et al. ${ }^{[2]]}$ in UK and Ireland, they reported that oxacillin-sensitive CoNS had the highest resistance against penicillin (75.5\%) and TMP-SMX (52\%). In the study conducted by Kim et al. ${ }^{[15]}$ in Korea, they found that the highest resistance was against penicillin $(96.8 \%)$, oxacillin (84.7\%) and erythromycin (71.3\%). In the study conducted by Kaya et al. ${ }^{[18]}$ in Turkey, they determined that the highest resistance was against penicillin (70.4\%) and erythromycin (68.1\%). In this study, the highest antibiotic resistance was found against penicillin G (85.7\%), SAM (78.6\%) and TMPSMX (75\%). These results show that CoNS has the highest resistance against penicillin-group antibiotics, erythromycin and TMP-SMX.

Karlowsky et al. ${ }^{[20]}$ reported that $\mathrm{S}$. aureus had the highest antibiotic resistance against penicillin (85.7\%) and erythromycin (30.9\%).Reynolds et al. ${ }^{[21]}$ reported that oxacillin-sensitive $S$. aureus had the highest resistance against penicillin (82.5\%) and TMP-SMX (31.4\%). Kim et al. ${ }^{[15]}$ found that the highest resistance was against penicillin (95.4\%) and oxacillin (69.8\%). In the study conducted by Hill et al. ${ }^{[7]}$ in Gambia, they reported that the highest resistance was against penicillin (71.4\%), tetracycline (66.6\%) and TMP-SMX (33.3\%).In a meta-analysis study related with Africa conducted by Reddy et al. ${ }^{[22]}$ they reported that the highest resistance was against ampicillin (90.9\%), tetracycline (56.5\%) and erythromycin (43.5\%). In the study conducted by Blomberg et al. ${ }^{[23]}$ in Tanzania, they found that the highest resistance was against penicillin (100\%), doxycycline (65\%) and ACA (50\%). Kaya et al. ${ }^{[18]}$ reported that the highest resistance was against penicillin (95.8\%) and erythromycin (83.3\%). In this study, the highest antibiotic resistance was found against penicillin $\mathrm{G}$ (86.7\%), SAM (80\%) and TMP-SMX (73.3\%). In accordance with these results, $\mathrm{S}$. aureus has the highest resistance against penicillin- and tetracycline-group antibiotics, erythromycin and TMP-SMX.
Karlowsky et al. ${ }^{[20]}$ reported that the highest antibiotic resistance in E. coli was against ampicillin (47.8\%) and cephalothin (35.5\%). Reynolds et al. ${ }^{[21]}$ determined that the highest resistance was against tigecycline (89.2\%), minocycline (88.4\%) and ACA (56.2\%). Kim et al. ${ }^{[15]}$ reported that the highest resistance was against ampicillin (63.4\%), piperacillin (44.2\%) and TMP-SMX (37\%). Hill et al. ${ }^{[7]}$ that reported the highest resistance was against ampicillin (100\%), and TMP-SMX (77.8\%). Reddy et al..22] found that the highest resistance was against ampicillin (91.9\%), tetracycline (91.9\%) and TMP-SMX (83.1\%). Blomberg et al. ${ }^{[23]}$ stated that the highest resistance was against ampicillin (85\%), TMP-SMX (77\%) and doxycycline (77\%). Kaya et al. ${ }^{[18]}$ reported that the highest resistance was against ampicillin (91.6\%) and ACA $(60 \%)$.In this study, the highest antibiotic resistance was found against TMP-SMX with $80 \%$ and ampicillin, ACA, ceftriaxone and cefoxitin with $60 \%$. Thus, these results show that $E$. coli has the highest resistance against penicillin, tetracycline- and cephalosporin-group antibiotics and TMP-SMX.

\section{CONCLUSION}

In conclusion, distribution of sepsis-causing microorganisms and their antibiotic susceptibilty vary over time and between different geographical locations. Therefore, it is necessary that conducting studies on this subject and that taking the results of such studies into account while designing an appropriate empirical therapy. In this wise, it was concluded that morbidity and mortality may be reduced and development of antibiotic resistance may be prevented.

\section{ETHICAL DECLARATIONS}

Ethics Comittee Approval: The study was carried out with the permission of Mogadishu, Somalia Turkey Recep Tayyip Erdogan Training and Research Hospital Ethics Committee (Decision dated 25.12.2018/96 and numbered MSTH/5395). The study was also conducted in accordance with the Declaration of Helsinki.

Informed Consent: Because the study was designed retrospectively, no written informed consent form was obtained from patients.

Status of Peer-review: Externally peer-reviewed.

Conflict of Interest Statement: The authors have no conflicts of interest to declare.

Financial Disclosure: The authors declared that this study has received no financial support.

Author Contributions: All of the authors declare that they have all participated in the design, execution, and analysis of the paper, and that they have approved the final version.

\section{REFERENCES}

1. Garg A, Anupurba S, Garg J, Goyal RK, Sen MR. Bacteriological profile and antimicrobia resistance of blood culture isolates from a university hospital. JIACM. 2007; 8(2): 139-43. 
2. Ding JG, Sun QF, Li KC, et al. Retrospective analysis of nosoc omial infections in the intensive care unit of a tertiary hospital in China during 2003 and 2007. BMC Infect Dis. 2009; 9: 115.

3. Stoesser, N, Moore CE, Pocock JM, et al. Pediatric bloodstream infections in Cambodia, 2007 to 2011. The Pediatr Infect Dis J. 2013;32(7):e272-e76

4. Rosenthal VD. Health-care-associated infections in developing countries. Lancet. 2011; 377: 186-88.

5. Aiken AM, Mturi N, Njuguna P, et al. Risk and causes of paediatric hospitalacquired bacteraemia in Kilifi District Hospital, Kenya: a prospective cohort study. Lancet. 2011;378:2021-27.

6. Berkley JA, Lowe BS, Mwangi I, et al. Bacteremia among children admitted to a rural hospital in Kenya. N Engl J Med. 2005; 352: 39-47.

7. Hill PC, Onyeama CO, Ikumapayi UN, et al. Bacteraemia in patients admitted to an urban hospital in West Africa. BMC Infect Dis. 2007; 7: 2.

8. Bahwere $P$, Levy J, Hennart $P$, et al. Community-acquired bacteremia among hospitalized children in rural central Africa. Int J Infect Dis. 2001; 5:180-8.

9. Blomberg $B$, Jureen $R$, Manji KP, et al. High rate of fatal cases of pediatric septicemia caused by gram-negative bacteria with extended-spectrum beta-lactamases in Dar es Salaam, Tanzania. J Clin Microbiol. 2005;43:7459.

10. Khaleel ME, Lone DS, Munir M, Khan JK, Zahra K, Hanif A. A study of microbial isolates from blood at a University Teaching Hospital. Annals King Edward Medical University. 2010;16(3):194-7.

11. Mehta M, Dutta P, Gupta V. Antimicrobial susceptibility pattern of blood isolates from aa teaching hospital in north India. Jpn J Infect Dis. 2005; 58(3):174-6.

12. Mehli M, Gayyurhan ED, Zer $Y$, Akgün S, Özgür Akın FE, Balcı İ. Microorganism isolated in blood cultures in the Gaziantep University hospital and their susceptibility to antibiotics. Turk J Infect. 2007;21:141-5.

13. Clinical and Laboratory Standards Institute. Methods for Dilution and Antimicrobial Susceptibility Tests for Bacteria That Grow Aerobically; Approved Standard. 9th ed. Wayne, PA: Clinical and Laboratory Standards Institute; 2012.

14. Winn W, Allen S, Janda W et al. Koneman's Color Atlas and Textbook of Diagnostic Microbiology. 6th ed. Philadelphia: JB Lippincott, 2006; 98-9.

15. Kim HJ, Lee NY, Kim S, et al. Characteristics of microorganisms isolated from blood cultures at nine university hospitals in Korea during 2009. Korean J Clin Microbiol. 2011;14(2):48-54.

16. Safak B, Kilinc O. Microorganisms Isolated From Blood Cultures During 2010-2015 and Their Antimicrobial Susceptibilities. Klimik J. 2016;29(2):60-5.

17. Hoenigl M, Wagner J, Raggam RB, et al. Characteristics of hospitalacquired and community-onset blood stream infections, South-East Austria. PLoS One. 2014;9(8):e104702.

18. Kaya S, Arıdoğan BC, Çetin H, Demirci M. Isolated microorganisms in blood culture received children patients and antibiotic resistances. Firat Med J. 2007;12(1):34-6

19. Morkel G, Bekker A, Marais BJ, Kirsten G, Van Wyk J, Dramowski A. Bloodstream infections and antimicrobial resistance patterns in a South African neonatal intensive care unit. Paediatr Int Child Health. 2014;34(2):108-14.

20. Karlowsky JA, Jones ME, Draghi DC, Thornsberry C, Sahm DF, Volturo GA. Prevalence and antimicrobial susceptibilities of bacteria isolated from blood cultures of hospitalized patients in the United States in 2002. Annals Clin Microbiol Antimicrob. 2004; 3(1): 7

21. Reynolds R, Potz N, Colman M, Williams A, Livermore D, MacGowan A. Antimicrobial susceptibility of the pathogens of bacteraemia in the UK and Ireland 2001-2002: the BSAC Bacteraemia Resistance Surveillance Programme. J Antimicrob Chemother. 2004;53(6):1018-32.

22. Reddy EA, Shaw AV, Crump JA. Community-acquired bloodstream infections in Africa: a systematic review and meta-analysis. Lancet Infect Dis. 2010;10(6):417-32.
23. Blomberg B, Manji K, Urassa WK, et al. Antimicrobial resistance predicts death in Tanzanian children with bloodstream infections: a prospective cohort study. BMC Infect Dis 2007;7(1):43. 